\title{
Co robić? Poezja najnowsza wobec teorii wspólnych światów
}

Alina Świeściak

TEKSTY DRUGIE 2020, NR 5, S. 156-175

DOI: 10.18318/td.2020.5.10 | ORCID: 0000-0003-0459-1242

$\mathbf{F}$ liacje między sztuką, w tym literaturą, i teorią były i są obustronne. $Z$ tego powodu zresztą jedna i druga są narażone na zarzuty: zapuszczająca się na tereny artystyczne teoria wydaje się często za mało naukowa, a sztuka wsparta na teorii - nazbyt skomplikowana lub nużąca. Weźmy Manifesto, film w reżyserii Juliana Rosefeldta (2015), w którym jedynymi „kwestiami” wypowiadanymi przez bohaterów (we wszystkich „rolach głównych” - Cate Blanchett) są fragmenty awangardowych manifestów: od futurystycznych do nowofalowych (Godard). Film wydaje się dosyć ryzykownym przedsięwzięciem - oparta na grze jednej aktorki i przesterowana teoretycznie koncepcja przerosła oczekiwany skutek społeczny, jakim miało prawdopodobnie być badanie skuteczności awangardowych teorii we współczesnym świecie. Ten sam materiał zaprezentowany w galerii na trzynastu symultanicznie pracujących ekranach to już jednak inna sprawa. Tu sztuka i teoria - w jakiejś mierze ze względu na zamanifestowaną artystyczność - uzgodniły się o wiele lepiej.

\section{Alina Świeściak - profesor w Instytucie Literaturoznawstwa Uniwersytetu Śląskiego. Zajmu- je się literaturą dwudziestowieczną i najnowszą. Ostatnio wydała książkę Współ- czynnik sztuki. Polska poezja awangardowa i postawangardowa między autonomiq a zaangażowaniem (2019); redaktor naczelna Kwartalnika Kulturalnego „Opcje”, członkini kapituły Nagrody im. Wisławy Szymborskiej.}


Związek sztuki i teorii często bywa udany, a nieraz wydaje się wręcz niezbędny. Jest tak w przypadku sztuki eksperymentalnej. Uwikłany w teorię estetyczny eksperyment zwiększa swój polityczny potencjał: teorie stanowią budulec awangardowych utopii, a te napędzają mechanizm społecznej krytyki. Oto jeden z powodów, dla których awangarda jest projektem długiego, a może nieskończonego trwania'. Stawiając sobie niemożliwe do zrealizowania cele, ich osiągnięcie nieuchronnie powierza przyszłości.

Film Rosefeldta i problem awangardy nie są tu bez znaczenia - w tym szkicu chciałabym przyjrzeć się kilku pasmom powiązań poezji i teorii, które wspierają właśnie awangardowe myślenie o sztuce. Najogólniej rzecz ujmując, chodzi o splecione ze sobą teorie zatrudnione w kwestiach społecznych, politycznych, ekonomicznych, afektywnych, etycznych i estetycznych równocześnie. Nie są to "mocne" teorie (w znaczeniu, jakie nadaje temu terminowi Gianni Vattimo ${ }^{2}$ ), raczej teorie nastawione na negocjacje, nieimperialne - ale i niemarginalne ${ }^{3}$. Ich nieimperialność wynika z usytuowania „pomiędzy”, nie bez znaczenia wydaje się też jednak przerobiona lekcja postmodernizmu jako kierunku stotalizowanego przez teorię. Doświadczenie niezobowiązującego społecznie poststrukturalizmu skutkuje postawą przeciwstawną: zaangażowaniem. Są to więc teorie pomyślane „wdrożeniowo", krytyczne wobec zastanego porządku, nastawione na wspólnotowe projektowanie zmiany ${ }^{4}$.

1 Tak widzi to Hal Foster. Zob. tegoż Powrót realnego. Awangarda u schyłkuXX wieku, przeł. M. Borowski, M. Sugiera, Universitas, Kraków 2010, s. 18.

2 Vattimo, jako zwolennik „myśli słabej”, przeciwstawia się przede wszystkim właściwej dla nowoczesności dominującej pozycji podmiotu i skonstruowanym przez niego narzędziom społecznej i kulturowej kontroli. Teorie, o których będę pisać, próbują raczej zreferować sposoby produkowania takiej podmiotowości, same opowiadając się za podmiotem jako jednym z równoprawnych aktorów sieci, w której znajdują się również aktorzy nie-ludzcy.

3 Tę paradoksalną, mocną w jej słabości pozycję teorii dobrze ujmuje Bruno Latour we wstępie do Polityki natury, zapowiadając, że będzie nieustannie mediował między nauką, polityką i naturą, żadnej z nich nie przyznając większego autorytetu niż pozostałym: „Wydaje nam się zresztą, że słabość może nas zaprowadzić dalej niż siła. [...] Nasz brak autorytetu oznacza dokładnie gwarancję, że nie wykorzystamy nauki, by przysłużyć się polityce, ani polityki, by wysługiwać się nauce". B. Latour Polityka natury. Nauki wkraczają do demokracji, przeł. A. Czarnacka, wstęp M. Gdula, Wydawnictwo Krytyki Politycznej, Warszawa 2009, s. 19.

4 Podobnie o teoriach zaprezentowanych w antologii Teorie wywrotowe myśli ich redaktorka Agnieszka Gajewska. Bierze ona jednak pod uwagę głównie teorie postfeministyczne, korygujące feminizm głównonurtowy. Zob. Teorie wywrotowe. Antologia przekładów, red. A. Gajewska, Wydawnictwo Poznańskie, Poznań 2012. 
Autorami pierwszych pomyślanych w ten sposób teorii są z jednej strony Ernesto Laclau i Chantal Mouffe (Hegemonia i socjalistyczna strategia ${ }^{5}$ ), z drugiej Gilles Deleuze i Félix Guattari (dylogia Anty-Edyp. Kapitalizm i schizofrenia ${ }^{6}$ ). Ich koncepcje znajdują kontynuatorów m.in. u Brunona Latoura, Donny Haraway, Karen Barad, Isabelle Stranger, Judith Butler czy Rosi Braidotti. Do tych właśnie autorów i autorek będę się w tym szkicu odwoływać.

Twórczość poetek i poetów, o których mam zamiar pisać, chce być traktowana performatywnie. Nawet jeżeli oferuje „tylko” projekt albo gdy jej główna siła jest wyłącznie krytyczna, projekt ten można potraktować jako interwencję w społeczne praktyki. Mimo że „nigdy nie byliśmy nowocześni”, od czasu do czasu bywamy awangardowi. Awangardę można wszak przedstawić jako antynowoczesny projekt antyseparacyjny ${ }^{7}$. Przywoływani tu poeci i poetki byliby wówczas jego częścią?.

\section{Sosnowski polityczny}

Dobrym przykładem nowej orientacji w polskiej poezji i krytyce jest zmiana w twórczości i recepcji twórczości Andrzeja Sosnowskiego.Ten, powiedzieliby niektórzy, najważniejszy polski poeta po 1989 roku, a zarazem czołowy przedstawiciel poezji postmodernistycznej wraz z wydaniem Domu ran ${ }^{9}$ rozpoczął nowy etap swojej poetyckiej aktywności, co ważniejsze jednak, równocześnie zaczął się nowy rozdział jej krytycznej recepcji, określony przez myślenie polityczne, orientujące się przede wszystkim na postsytuacjonistyczną krytykę kapitalistycznego spek-

5 E. Laclau, Ch. Mouffe Hegemonia i socjalistyczna strategia. Przyczynek do projektu radykalnej polityki demokratycznej, przeł. S. Królak, wstęp S. Sierakowski, Wydawnictwo Naukowe Dolnośląskiej Szkoły Wyższej Edukacji TWP we Wrocławiu, Wrocław 2007.

6 G. Deleuze, F. Guattari Anty-Edyp. Kapitalizm i schizofrenia, przeł. T. Kaszubski, Wydawnictwo Krytyki Politycznej, Warszawa 2017; tychże Tysiąc plateau, red. merytoryczna i językowa J. Bednarek, Fundacja Bęc Zmiana, Warszawa 2016.

7 Książka Nigdy nie byliśmy nowocześni. Studium z antropologii symetrycznej (przeł. M. Gdula, Oficyna Naukowa, Warszawa 2011) to pierwszy wykład Brunona Latoura z serii "splątanych teorii". Na niemożności oddzielenia faktu od wartości - wbrew "separatystycznym" sądom na jej temat - zbudowana jest nowoczesność.

8 Taki - nieseparacyjny, nowomaterialistyczny - sposób rozumienia współczesnej polskiej poezji od jakiegoś czasu upomina się już o uwagę. Wiele dla takiego jej rozumienia zrobiła Anna Kałuża. Jego dzisiejszymi rzecznikami są również Monika Glosowitz, Dawid Kujawa, Jakub Skurtys, Paweł Kaczmarski, Rafał Wawrzyńczyk czy Łukasz Żurek.

9 A. Sosnowski Dom ran, Biuro Literackie, Wrocław 2015. 
taklu. Piszę „co ważniejsze”, ponieważ moim zdaniem większa zmiana nastąpiła w recepcji niż w samej poezji Sosnowskiego ${ }^{10}$. Co prawda Dom ran wypełniony jest obrazami kanibalistycznego kapitalistycznego spektaklu, a Sosnowski stosuje taktykę nieprzejrzystości, uniemożliwiającą łatwe zawłaszczenie jego metody przechwytywania reguł tego spektaklu, nadal jednak bliskie mu jest myślenie kategoriami estetycznej autonomii. Krytyka społeczna wynika tu z ironicznie potraktowanej idei zniesienia sztuki w praktyce życiowej,która to wchłonęła sztukę, a właściwie przelicytowała ją, ale nie na awangardowych zasadach. Chodzi bowiem o sztukę klasy B, tę spod znaku kiepskiego horroru czy farsy, która narzuciła społecznej rzeczywistości własne scenariusze (jak ten z wyspy Utoya), rzecz jasna nie w imię nowego społecznego ładu. Emancypacyjna siła sztuki, także wjej najbardziej progresywnym, awangardowym wydaniu, nie przedstawia się tu więc szczególnie imponująco. Z drugiej strony jednak obiecująca z tej perspektywy wydaje się sztuka pozornie najmniej progresywna - wczesnomodernistyczna, alegoryczna, estetycznie zorientowana twórczość Charles'a Baudelaire'a. Sosnowski przepracowuje w Domu ran modernistyczne kategorie estetyczne, takie jak (po Benjaminowsku pojęta) alegoria czy splin, wydobywając z nich polityczny potencjał. Nie przekreśla jednak idei estetycznej autonomii w jej postmodernistycznej postaci, raczej ją poszerza, komplikuje. Nie przebijamy się tu do niezmediatyzowanej i niezestetyzowanej rzeczywistości - jakkolwiek rzeczywistość ta wiele mówi o środowisku, w którym żyjemy. Jak w Matriksie sióstr Wachowski: coś, co wydaje się rzeczywiste, jest - lub tylko może być, ale nie będziemy tego wiedzieć na pewno - kolejną wersją matriksa.

Ważny wydaje mi się jednak gest młodych krytyków i krytyczek, którzy postanowili „odzyskać" Sosnowskiego dla swoich koncepcji literatury ${ }^{11}$. Jest on zbyt ważną postacią w polskiej współczesnej poezji, by dających szanse politycznego czytania sytuacjonistycznych tropów w ten sposób nie wykorzystać.

\section{"Idiotyczne propozycje"}

Innych przywoływanych tu poetów i poetek nie trzeba politycznie „odzyskiwać", ich twórczość dobrze zgrywa się z nowomaterialistycznym czy

10 Pisałam o tym w książce Współczynnik sztuki. Polska poezja awangardowa i postawangardowa między autonomiq̨ a zaangażowaniem (Wydawnictwo UJ, Kraków 2019), w rozdz. Co - to jest poezja. Andrzeja Sosnowskiego lekcja awangardy.

11 Zob. np. D. Kujawa Gdzie ma się schować takie życie (Andrzej Sosnowski: „Dom ran”), "artPapier” 2015, http://artpapier.com/index.php?page=artykul\&wydanie=286\&artykul=5189 (10.06.2020). 
postkonstruktywistycznym myśleniem o świecie. Towarzyszący im krytycy, w ślad za nowomaterialistycznymi badaczkami, podkreślają, że dominujący wcześniej podział na formę i materię (kulturę i naturę; to, co globalne, i to, co lokalne; symboliczne i materialne itd.) wiąże się z władzą i skutkuje wykluczeniem. Będę więc pisać o autorach i autorkach o rozbudowanej wyobraźni ekologicznej i dużej świadomości genderowej, ekonomicznej, społecznej, krytycznych wobec kapitalistycznych reguł ponowoczesnego świata oraz projektujących utopie innego świata i reguły innej niż modernistyczna konstytucji (Latour). Ich teksty to poligon doświadczalny, na którym dokonują się przegrupowania, ujawniają się mechanizmy manipulacji, ucisku, ale też zawiązują się sojusze konieczne do przekształcenia praktyk dyskursywno-materialnych.

Warunkiem wprowadzenia tej nowej, materialno-semiotycznej konstytucji jest inna niż modernistyczna i postmodernistyczna pozycja podmiotowości. W ramach tradycji liberalnej podmiot nie ujawniał nierówności, teraz dynamizuje się, włącza w projekt transklasowej, transpłciowej, transgatunkowej czy - jeszcze szerzej - transnaturalnej solidarności. W zrozumieniu sposobów istnienia tego podmiotu i reguł jego estetyczno-politycznej aktywności pomagają koncepcje teoretyczne wymienionych wyżej autorów, stawiające na symbiotyczne połączenia, ciągłość, splatanie, splątanie, tworzenie sieci ludzkich i nie-ludzkich aktorów.

Polityczność w omawianych przeze mnie wierszach produkowana jest oddolnie i nie rości sobie pretensji do władzy - nie chce dla siebie głosu politycznego, raczej chce działać politycznie przez stawianie oporu głosom politycznym. Można by ją wtedy porównać do reakcji idioty, którego Isabelle Stengers, za Deleuze'em przyglądającym się bohaterowi Dostojewskiego, rozumie jako tego, który przeciwstawia się jasnym, pragmatycznym czy pożądanym rozwiązaniom, zawsze opóźnia proces dochodzenia do konsensusu, ale nie w imię innych niż dominujące racji, tylko z powodu „czegoś ważniejszego", co nigdy nie zostanie wyartykułowane. Swoją propozycję, daleką od pewności, bliższą strachowi, Stengers nazywa kosmopolityczną, co znaczy tyle, że dotyczy ona sytuacji, w której polityczne spotyka się z kosmicznym - konieczność zadawania uporczywych pytań z milczącą obecnością tego, co musi pozostać na nie głuche ${ }^{12}$. Jej pragmatyczny wymiar zaś polega na politycznej aktywności, zaangażowaniu w eksperymentowanie ze zmianą, przekreślające

12 Zob. I. Strengers Propozycja kosmopolityczna, przeł. A. Kowalczyk, w: Ekologie, red. A. Jach, P. Juskowiak, A. Kowalczyk, K. Szadkowski, Muzeum Sztuki w Łodzi, s. 136-156, https://msl.org.pl/ media/user/pdf/ekologie-ebook-pdf.pdf (5.06.2020). 
jakiekolwiek z góry określone postawy. W takim ujęciu interesujący mnie tu poeci i poetki to autorzy i autorki rozlicznych „idiotycznych" propozycji konfrontowania się ze światem na własną rękę i na własną odpowiedzialność - chociaż w imię „wspólnego dobra”, „wspólnego świata”, które muszą pozostać kategoriami otwartymi, stale domagającymi się przemyślenia.

Wszyscy oni uprzywilejowują pewne pola dyskursu, nie tracąc z oczu relacyjnej „całości”. Na przykład w wierszach Szczepana Kopyta czy Ilony Witkowskiej myślenie ekologiczne idzie w parze z analizą stosunków władzy w ramach semiokapitalizmu, Kira Pietrek i Adam Kaczanowski na różne sposoby etycznie sprawdzają język reklamowo-korporacyjny; Tomasz Bąk splata w swoich wierszach język ekonomii, religii i polityki; Kacper Bartczak, Anna Adamowicz, Monika Lubińska pracują z filozofią nomadyczną; Konrad Góra politycznie aktywizuje techniki surrealizmu; Kamila Janiak przepracowuje strategie punkowe. W żadnym z tych poetyckich przypadków materialny charakter dyskursu (jego sprawczość) nie zostaje ostatecznie scalony - zaproponowane wyżej scalenia również są tymczasowe. Są to (by odwołać się do Ernesta Laclau i Chantal Mouffe) nieciągłe wiązania ${ }^{13}$, intra-akcje (według Karen Barad ${ }^{14}$ ) albo procesy stawania się czy deterytorializacje (Deleuze, Guattari' ${ }^{15}$ ), a więc praktyka dyskursywno-materialna polegająca na zmiennych, otwartych konfiguracjach i rekonfiguracjach tego, co językowe, z tym, co materialne.

Autorów i autorek, których można by uwzględnić w tym intra-aktywnym projekcie, jest dużo więcej, m.in. kilkoro zeszłorocznych debiutantów i miasto Kraków, które po konsultacjach przeprowadzonych przez Piotra Mareckiego napisało i wydało eksperymentalny raport smogowy ${ }^{16}$.

\section{Kapitalizm i utopia (Szczepan Kopyt i Tomasz Bąk)}

W tekstach Szczepana Kopyta i Tomasza Bąka języki „obce poezji” - język marksistowskiej filozofii (Kopyt) i ekonomii kapitalizmu (Bąk)

13 Dla Laclau i Mouffe wiązania te są efektem "niezszytej” przestrzeni tego, co społeczne, i nieskończonego pola dyskursywności. Zob. E. Laclau, Ch. Mouffe Hegemonia i socjalistyczna strategia, s. XIII-XIV.

Zob. K. Barad Poshumanistyczna performatywność: ku zrozumieniu, jak materia zaczyna mieć znaczenie, przeł. J. Bednarek, w: Teorie wywrotowe, s. 323-360.

15 Zob. G. Deleuze, F. Guattari Stawanie-się-intensywnym, stawanie-się-zwierzęciem, stawanie-się-niedostrzegalnym, w: tychże Tysiąc plateau, s. 281-375. 
- kontaktują się w ramach wiersza z elementami innych porządków, tworząc układ oparty na chwilowych, częściowych stabilizacjach (w języku Laclau i Mouffe - „punkty węzłowe”), otwarty na nowe możliwości krytyczne. Laclau i Mouffe nazwaliby to naddeterminacją i zapewnili, że w ten sposób negocjuje się granice tego, co społeczne, i tego, co podmiotowe ${ }^{17}$. Przyjrzyjmy się wierszowi Kopyta (z tomu $z a b i c^{18}$ ) i fragmentowi Bailoutu Bąka (z tomu Bailout ${ }^{19}$ ):

wyobraź sobie wiersz pojawiający się znikąd w tłumnym centrum sączący się z głośników wprost do ust pracownic i pracowników rzucających swoje tace rękawice zniszczone fragmenty infrastruktury

wiersz który sprawia że idą w jedną stronę poemat którego emocje finalne splatają losy osobiste z momentem wybuchu lirykę która niszczy bankomaty wersy na ustach kibiców

przechodzących do gry tak wiersz który nie napuszcza na siebie wiersz nieurywający się ani na moment dopasowany jak tampon wiersz z którego nieuważni czerpią uwagę a uważni siłę

wyobraź sobie tekst generujący ciągi zdarzeń wiersz jak kroplę $\mathrm{i}$ bombę z cyfrowym detonatorem strofy nielokujące produktów metafory obrysowane na ogólnych teoriach rynku i fizjologii

wiersz o estetyce lustra radia gazety telewizji i outdoorów wiersz odbierany inaczej przez psy koty i ludzi inaczej przez kobiety inaczej przez mężczyzn inaczej przez inne role

wiersz inaczej rozumiany przez bliźniaki jednojajowe inaczej przez klon człowieka i jego biopatern wiersz w którym wszystko można jeszcze zepsuć i ulepszyć

Zob. E. Laclau, Ch. Mouffe Hegemonia i socjalistyczna strategia, s. 13-14.

18 S. Kopyt zabic, WBPiCAK, Poznań 2016. 
wiersz to tak naprawdę dwa w jednym: wiersz o wyobrażonym wierszu. Ten pierwszy raczej jest, ten drugi, w którym „wszystko można jeszcze zepsuć i ulepszyć", raczej działa. Oto pierwsza płaszczyzna jego naddeterminacji (stabilności/niestabilności). Kolejną tworzą uwspólnione/zantagonizowane sensy estetyczne i społeczno-polityczne. Można by powiedzieć tak (nadal w pamięci mając Laclau i Mouffe): to, że wiersz staje się tu politycznym działaniem, umożliwia antagonizm estetycznego i politycznego, a więc niemożność utrwalenia granic między nimi. „Sygnatariuszami” tego antagonizmu byłyby metafory, zaburzenia procedowania każdego z nich z osobna, każące zapełniać obecne w nim luki na zewnątrz, w drugim języku. Tych metaforycznych splotów jest tu sporo. Wystarczy przyjrzeć się temu, co robi ten wiersz: sączy się z głośników do ust pracownic i pracowników; sprawia, że idą oni w jedną stronę; jego emocje finalne splatają losy indywidualne z momentem wybuchu; niszczy bankomaty, jego wersy są na ustach kibiców przechodzących do gry, a on sam jest jak bomba z cyfrowym detonatorem - to tylko część politycznych, a właściwie rewolucyjnych „aktywności” wiersza, ale aktywności uwikłanych w wersowość, ustność, dźwięczność, poetyckość. I jeszcze jedna płaszczyzna naddeterminacji, dotycząca pozycji podmiotowych. Odbiorcą tego wyobrażonego wiersza może być każdy (kto chce zmienić kapitalistyczny porządek), ale „każdy” oznacza tu maksymalnie szeroki zestaw ról, a więc właśnie pozycji podmiotowych: człowieka, zwierzęcia, klona, w ich najróżniejszych odmianach.

Wydaje się, że wpisany w wiersz projekt wiersza można uznać za utopijny projekt awangardowy, gdzie estetyka i polityka pracują wspólnie na rzecz uzgodnionych celów: eksperymentalnej sztuki, społecznej rewolucji i - szerzej - przeformułowania myślenia o tym, co estetyczne, i o tym, co społeczne (dyskursywne, materialne, afektywne, aktywne, ludzkie i nie-ludzkie). Ścieżki stabilizacyjne zaprojektowane są tak, by kwestionując granice praktyk instytucjonalnych, utrzymać tę dynamiczną równowagę.

Ostatni tom Tomasza Bąka, na który składają się długi poemat Bailout i przypisy do niego, to poetycki wykład o ekonomii kapitalizmu, proponujący przeprogramowanie naszego myślenia z logiki zysku na „empatyczną utopię”. Poeta po tym, jak odwołując się do przykładów z teorii i historii klasycznej ekonomii, wyjaśnił etiologię kapitalistycznego kryzysu, zarysował drogę wyjścia z niego. Antidotum znane jest niby skądinąd, a jednak inne:

Choć ostatnim celem komunizmu jest zniesienie stosunku klasowego 
między kapitałem a praca, nie musi to pociągać za sobą likwidacji pieniądza (a także muszelek, rzemyków i boukcoinów) oraz wymiany dóbr i usług.<smiles>[CH]1C[CH]C1</smiles>

Przeistoczenie

Przeistaczanie

Rekonfiguracja ruchów okrężnych może przysporzyć kantów.

Nieuchwytność procesów społeczno-ekonomicznych nie oznacza ich deterytorializacji i dematerializacji.

Zacząć jeszcze raz.

Musimy wyobrazić sobie świat, w którym przyszłość nie jest tylko kontynuacją teraźniejszości.<smiles>[CH]1[CH]CC1</smiles>

Musimy głębiej przemyśleć to, czy to, czego potrzebujemy, faktycznie wynika z naszych potrzeb.

I czy na pewno to, czego chcemy, przysłuży się nam i osobom w naszym otoczeniu.

Człowiek ekonomiczny w poszukiwaniu zaginionej empatii.

Odwrócenie trendu funkcji empatii do czasu, początek empatycznej utopii. 
Spotkajmy się w punkcie przegięcia, nawet jeśli brzmi to jak prowokacja.

Podlejmy utopię, by mogła się ukorzenić.<smiles>C1[AlH][AlH]1</smiles>

Musimy pobudzić popyt na ludzi.<smiles>C1[AlH][AlH]1</smiles>

Potrzeba wielu starań, by zobaczyć to, co się wyłania.

A widzę to tak:

wstaniemy o świcie, w pierwszych odbłyskach dnia, skrzące latarnie wskażą nam drogę do fabryk i biur, które będą nam drogie i nigdy nie będziemy chcieli pamiętać czasów, w których należały do kogoś innego, nasze dniówki będą pełne niby źrebne klacze, nasze cele zostaną ustalone wspólnie, nasze deadline'y wreszcie będą bezpieczne.

Nikt nie zamachnie się na nich ani na nas, nigdy więcej wojen o ropę i organy. Wydatki na zbrojenia będziemy wspominać jako kiepski żart. Będzie za to kasza i okrasa, nikt nie będzie umierał w niedogrzanych mieszkaniach. O potrzebach będziemy rozmawiać w miejscach, w których końce się wiążą.

Naiwne? Być może, czas, by świat potraktował naiwność jak cnotę.

Preguntando caminamos. 
Poemat będący od początku do końca krytyką kapitalizmu zamyka utopijna wizja komunistycznego ładu, zakorzenionego nie w europejskiej, marksistowsko-leninowskiej koncepcji, która domaga się przełożenia na realia władzy politycznej, ale koncepcji meksykańskich zapatystów, opartej na etyce godności, bez aspiracji do władzy („Preguntando caminamos”20). Wcześniej pojawia się „empatyczna utopia”, która ma być podlewana, by mogła się ukorzenić. W całym poemacie język ekonomii pracuje rzecz jasna na innych niż we własnej domenie zasadach, jest poetycko przechwytywany, logika kapitalistycznej ekonomii jest sprawdzana, a raczej kompromitowana za pomocą logiki życiowej, poddawana próbom etycznym. Kapitalizm jako taki - a szczególnie jego ponowoczesne, kognitywne wersje - jest tu denuncjowany jako kategoria materialno-dyskursywna, w której dyskursywność przejmuje władzę nad materialnością, a właściwie przechyla ją w kierunku dematerializacji (zarówno produkcji,jak i pieniądza).Zwycięstwo tak pojętej dyskursywności nie jest jednak oczywiste. Na niej wszak zasadza się wieloznaczność tego, co społeczne, a ta daje szansę na zmianę. Jak dyskursywność kapitalizmu pracuje na rzecz zmiany?

W przywoływanej tu już wielokrotnie książce Hegemonia $i$ socjalistyczna strategia Laclau i Mouffe interesują m.in. sposoby zaburzania dyskursu podporząadkowania. Jak piszą, może on zostać podważony wyłącznie przez zewnętrzny wobec niego element. Dobrze ilustruje to początek ruchu feministycznego. Aktem założycielskim feminizmu była zdaniem badaczy książka Mary Wollstonecraft Wotanie o prawa kobiety (Vindication of The Rights of Woman), która przeniosła dyskurs demokratyczny ze sfery politycznej równości obywateli na sferę równości płci ${ }^{21}$. Podporządkowanie kobiet w patriarchalnym społeczeństwie samo z siebie nie domaga się zmiany, kiedy jednak nazwiemy kobietę obywatelem, chcąc nie chcąc, uruchamiamy zasoby obywatelskiej „formacji dyskursywnej”, dzięki czemu zmiana może się dokonać.

Tomasz Bąk o ekonomii kapitalizmu pisze z perspektywy etycznej, afektywnej, emocjonalnej, sprywatyzowanej, każąc jej konfrontować się z sytuacjami, z którymi ta "normalnie” nie musi i nie chce tego robić. Włącza również dyskurs religijny - nie tyle jednak śledzi przepływ między ekonomią kapitalizmu a ekonomią religii, ile językowi zarezerwowanemu dla sfery religii każe opisywać poszczególne stadia „reżimu akumulacji” i stosunki towarowe (co oczywiście potwierdza ów przepływ). Rysujące się w ten

"Idziemy, pytając".

E. Laclau, Ch. Mouffe Hegemonia i socjalistyczna strategia, s. 162. 
sposób antagonizmy już to dekonspirują hegemoniczny projekt dyskursu liberalno-konserwatywnego (ekonomia i religia), już to zostają zatrudnione w procesie zmiany. Fakt, że żaden dyskurs społeczny nie jest ostatecznie wykrystalizowany, nie musi bowiem skutkować eskalacją jego władzy (tak bywa zazwyczaj rozumiany dyskurs liberalny - jako przechwytujący wszystkie rebelianckie próby zakwestionowania go), daje też szansę na poszerzenie pola walki. Wydaje się, że uaktywnienie emocjonalnych, afektywnych, etycznych powiązań między logiką kapitalizmu a logiką życia może pomóc w wypracowaniu nowej praktyki politycznej. Jest nią tu, na co wskazuje zakończenie, etyczno-afektywna ${ }^{22}$ rewolucja, mająca - na wzór zapatystowski - nie tyle zburzyć kapitalistyczny porządek, ile go „przeanielić”. Ostatecznie wychodzi na jedno, ponieważ naprawienie od środka zmieni go w komunizm. Tomasz Bąk nie każe nam wierzyć w szybkie "przeanielenie” rzeczywistości („Potrzeba wielu starań / by zobaczyć to, co się wyłania”), każe jednak zaufać potrzebie utopii.

\section{Bez utopii: kapitalizm i destrukcja \\ (Adam Kaczanowski, Kamila Janiak, Konrad Góra)}

Spotkanie etyki i kapitalizmu w książkach poetyckich Adama Kaczanowskiego i Kamili Janiak to zupełnie inna historia. Obydwoje projektują anarchistyczne scenariusze losów naszej planety. Dla Janiak jest to anarchia spod znaku punka, bliska „bezinteresownej negatywności” ${ }^{23}$. Jej bunt jest antyantropoiczny: „chciałabym najbardziej, żeby człowiek / zdychał, a reszta się patrzyła / i tak do ostatniego zgromadzenia" - czytamy w iskrze z jej debiutanckiego tomu frajerom śmierćc ${ }^{24}$. Gatunkowy holokaust to istotny temat także w twórczości Kaczanowskiego. Jego Cele ${ }^{25}$ to wymyślny zestaw pomysłów samobójczych dla wszystkich klas, ras i gatunków, próba społecznej wyobraźni autodestrukcyjnej. I w jednym, i w drugim przypadku - pierwszy bliższy jest estetyce punkowej, drugi poetyce absurdu - destrukcja i autodestrukcja są jakąś odpowiedzią na skumulowane kryzysy zaawansowanego kapitalizmu.

Na temat zapatyzmu zob. np. A. Khasnabish Zapatismo beyond Borders: New Imaginations of Political Possibility, University of Toronto Press, Toronto 2008.

Zob. na ten temat A. Świeściak Kamila Janiak i punk, w: tejże Współczynnik sztuki, s. 226-240. 
Etyka pomyślana jest tu oczywiście inaczej niż w tradycji chrześcijańskiej: destrukcja i autodestrukcja to naturalne i ze wszech miar pożądane stany rzeczywistości, niebędące karą - tym mniej karą za indywidualną winę. Ich naturalność można by łączyć z myśleniem w kategoriach etyki nomadycznej (Rosi Braidotti), zakładającej odpowiedzialność za trwałość życia. „Winny” okazuje się antropocen jako planetarna katastrofa wywołana przez ludzi.

„Co robić, kiedy mówi się nam codziennie i w coraz ostrzejszy sposób, że nasza cywilizacja jest skazana na zagładę; że tak bardzo majstrowaliśmy przy Ziemi, iż nie ma szans, by kiedykolwiek wróciła do któregoś ze swoich dawnych, stabilnych stanów?"26 - pyta Bruno Latour. Interesuje go niejednoznaczność etyczna tej sytuacji: „Jak tu doświadczać wzniosłości, kiedy gryzie nas sumienie? A gryzie nas ono w nowy, nieoczekiwany sposób, ponieważjest jasne, że to nie ja jestem odpowiedzialny - ani ty, ani wy. Nikt w pojedynkę nie jest za to odpowiedzialny"27. Problem polega na tym, że nie ma żadnego "my", które można by obciążyć odpowiedzialnością. Przynajmniej prawnie. W wierszach Kaczanowskiego i Janiak trochę argumentów na rzecz ludzkiego holokaustu by się jednak znalazło. Żeby dać odpowiedź na pytanie Latoura, trzeba sięgnąć na zewnątrz - jak powiedziałaby Mouffe, posłużyć się soczewkami innej gry językowejej.

W Co jest nie tak z tymi ludźmi $i^{29}$ mniej więcej naprzemiennie pojawiają się dwie pozycje nie-ludzkie: "Chyba jestem cyborgiem" $i$ „Jestem ostatnim drzewem". Ta zmiana perspektywy w dwóch kierunkach, stawania się rośliną i stawania się maszyną, gdyby pójść za Deleuze'em i Guattarim, pozwala spojrzeć na to, co ludzkie, w stałym ruchu w stronę innego - nie-ludzkie deterytorializuje i reterytorializuje ludzkie, tak że chwilowo zamieniają się one pozycjami. Istotna wydaje się tu też kategoria wielości. Kaczanowski „pracuje” z ludzkim stadem, mało interesują go indywidualne przypadki - jedynie jako egzempla; przez ich absurdalne skumulowanie uzyskuje efekt nieuchronności i totalności. Gdyby pójść dalej, w kierunku etyki stawania się (Braidotti), na efekty aktywności ludzkiego stada można by spojrzeć jako na degradację

26 B. Latour Czekając na Gaję. Komponowanie wspólnego świata przez sztukę i politykę, przeł. A. Kowalczyk, w: Ekologie, s. 158.

Zob. Ch. Mouffe Paradoks demokracji, wstęp L. Koczanowicz, przeł. W. Jach, A. Kamińska, A. Orzechowski, Wydawnictwo Naukowe Dolnośląskiej Szkoły Wyższej Edukacji TWP we Wrocławiu, Wrocław 2005, s. 141. 
wspólnej przestrzeni, zagrożenie trwałości życia ${ }^{30}$. Absurdalna akumulacja, katastrofalne nierówności, brak empatii, anestezja - innymi słowy, wszystkie grzechy neoliberalnego kapitalizmu - to w kategoriach etyki nomadycznej "grzech" przeciwko dobru wspólnemu, roślinno-zwierzęco-maszynowemu. Samoeksterminacja ludzkości wydaje się więc całkiem logicznym rozwiązaniem etycznego impasu. Kaczanowski nie proponuje nam żadnych wariantów ewakuacyjnych - żadnych utopii.„Odciążenie” uzyskujemy tu inaczej - oczywiście jeśli go potrzebujemy - dzięki purnonsensowemu, absurdalnemu zwielokrotnieniu efektu grozy.

Kamila Janiak niekiedy działa podobnie - z tekstów stanowiących klamrę Wierszy przeciwko ludzkośc $l^{31}$ pierwszy to bezkompromisowa diagnoza "Chmurko, jesteś toksyczna. / Serce, jesteś zatrute. / Człowieku, nie zasługujesz na walkę", a drugi to konsekwencje tej diagnozy - seria absurdalnie skumulowanych przypadków śmiertelnych (jak w Celach, które notabene zostały wydane w tym samym roku co Wiersze przeciwko ludzkości). W Jednej z wielu znajdziemy ponadto kilkakrotnie powtórzoną frazę „Jest coś nie tak” („z tymi ludźmi” albo raczej „z nami, ludźmi”) i antyutopijne zakończenie: „Nadzieja jest piekłem od urodzenia". Co prawda większość tekstów w tym tomie wydaje się - w przeciwieństwie do konceptualnej poezji Kaczanowskiego - klasyczniej ekspresywna, sprywatyzowana, są to jednak od początku do końca figury „osobistego" dopasowywania się, przymierzania do śmierci. Skoro ma ona objąć całą ludzkość - dotyczy również podmiotu tych wierszy. W poprzednich tomach temat destrukcji zapośredniczany był w estetyce muzycznej, filmowej, artystycznej, często wykorzystującej najróżniejsze kontrkulturowe apokaliptyczne scenariusze, przez co ustalenie się granicy między podmiotem a światem było niemożliwe. Podmiot-bohaterka świat podpala, pożera, na różne sposoby eksterminuje, ale i jest przez niego pożerana, niszczona, gwałcona. Te, jak powiedziałaby Barad, dyskursywno-materialne intra-akcje pozwalają jej wymykać się relacjom wiedzy-władzy, ciągle negocjować je na nowo. Serie zawiązywanych i zrywanych powiązań, zmieniające się jak w kalejdoskopie układy hegemoniczne sugerują, że w dzisiejszym świecie nie odbywa się jedna walka - z wrogiem, któremu na imię kapitalizm - a wiele

Etyką stawania się albo etyką trwałości nazywa Braidotti etykę nieunitarnie pojętej podmiotowości, opartą nie na poznaniu, ale na cielesnym, afektywnym zbliżaniu się do wszystkiego, co żyje. Zob. R. Braidotti Etyka stawania się niewykrywalnym, przeł. J. Bednarek, w: Teorie wywrotowe, s. 292-309.

K. Janiak Wiersze przeciwko ludzkości, WBPiCAK, Staromiejski Dom Kultury, Poznań 2018. 
powiązanych, ale nietożsamych ze sobą walk: genderowych, ekologicznych, rasowych, które chcą tu być walkami równoważnymi. Niewiele jednak wskazuje na ich pozytywne zakończenie, wyobraźnia Janiak coraz wyraźniej staje się więc wyobraźnią suicydalną. Tak jak w przypadku Kaczanowskiego, nie znajdziemy w tej poezji żadnych śladów koncepcji społecznej pozytywności. Wyznawana przez autorkę Wierszy przeciwko ludzkości logika społeczna jest logiką radykalnej negatywności. Twórczość obydwojga, zakorzeniona w teoriach lewicowych, rezygnuje z ich utopijnych aspektów. Co prawda, jak piszą Laclau i Mouffe, bez utopii nie da się zbudować demokracji - ani nawet solidnej myśli lewicowej ${ }^{32}$ - poezji ta niekonsekwencja jednak nie przeszkadza.

Konrad Góra nie jest poetą destrukcji, ale jest poetą gniewu, a destrukcja to eksperymentalnie potraktowany temat jednej z jego książek - poematu Nie ${ }^{33}$. Cała twórczość Góry mieści się w zarysowanej wyżej teoretycznej perspektywie: wszystko polega tu na intensywnych nieoczywistych grach znaczeń - wyobraźniowo odrealnionych, ale co rusz zderzających się z materialnością, cielesnością, bolesnością przeciążonej ekonomicznie, konsumpcyjnie, politycznie rzeczywistości. W interpretacji tych wierszy - oprócz koncepcji antyhegemonistycznych czy nowomaterialistycznych - można uaktywnić i inne, np. dobrze zaadaptowane u nas myślenie o politycznym potencjale estetycznej nieoczywistości, za którym stoi Jacques Rancière, albo mniej oczywistą, włączoną w manifest "nooawangardy” teorię bardzo rzadkich zdarzeń. W poemacie Nie słychać też echa filozofii Michela Foucaulta i Gilles'a Deleuze'a, wspomagających tu analizę (anty)logiki ekonomii śmierci ${ }^{34}$. Ten cykl 1127 dystychów, odpowiadających liczbie ofiar katastrofy w fabrykach odzieżowych w Rana Plaza, zachowuje idealny balans między opartą na nieprzejrzystości formą a wyraźnie ukierunkowanymi politycznymi intencjami, zorientowanymi na przepracowanie tego, co wyparte z dyskursu publicznego. Linie wiązań/zerwań odtwarzają strukturę ruin, zrównujących materialne i niematerialne, ludzkie i nie-ludzkie, a więc ciała, maszyny, budynki, naturę, sztukę i język. Materialność tego ostatniego odczuwany bardzo wyraźnie: w zerwaniach, zająknięciach, zapętleniach. Język jest więc zarówno, jak ludzie, ofiarą, jak i prominentnym udziałowcem dyskursywnej władzy neoliberalnej ekonomii i biopolityki. Projekt Góry jest również antyutopijny.

E. Laclou, Ch. Mouffe Hegemonia i socjalistyczna strategia, s. 199-200.

K. Góra Nie, Biuro Literackie, Stronie Śląskie 2016.

34 Zob. A. Świeściak "Laboratorium rzeczywistości”. Konrad Góra, w: tejże Współczynnik sztuki, s. $241-263$. 
Domaga się jedynie żałoby, ale i ona została deziluzyjnie oddelegowana do innego porządku - bajki $i^{35}$.

\section{Jeszcze raz utopia: ekopoetyckie pluriwersum (Kacper Bartczak, Anna Adamowicz, Monika Lubińska)}

W ramach opisanych poniżej projektów poetyckiego nomadyzmu procesy materialno-dyskursywnych wiązań, intra-akcji, stawania się zorientowane są na poszukiwanie nowych możliwości życia (w tym życia wiersza) i jego ochrony. W wierszach Kacpra Bartczaka „ekologia wiersza" to bardzo szeroka domena, sięgająca postsekularności; w tekstach Adamowicz i Lubińskiej materialność, ucieleśnienie i będąca ich produktem afektywność mają konotacje etyczne.

Świat poezji Kacpra Bartczaka można by nazwać - za Timem Ingoldem - światem materiałów ${ }^{36}$. Przejścia między tym, co wewnątrz, a tym, co na zewnątrz świata materialnego, dokonują się tu w sposób, który przeczy tym nawykowym podziałom. Mnogość rzeczowników należących do różnych dyskursów odpowiada wielości substancji, które to syntetyzują się, kondensują („W twojej syntezie kondensuje się sygnał”, Pozycja złóż z Wierszy organicznych $^{37}$ ), to spalają, destylują („Ocean substancji wymazuje miasto”, tamże), migrując między różnymi obszarami - albo raczej możliwościami, stanami rzeczywistości i języka. Jej organiczne, nieorganiczne, energetyczne, ekonomiczne, polityczne, nowomedialne, metafizyczne „nagromadzenia” są chwilowymi wiązaniami, podatnymi na zmianę jak u żadnego z wcześniej wymienionych autorów. „Ekologia wiersza” to właśnie dbałość o materiały i wiązania ${ }^{38}$. Fragmenty wiązań migrują w ramach całości, jaką stanowią poszczególne tomy, albo między nimi, tyleż konstytuując tę całość, ile blokując wszelkie próby zawężania tego pojęcia do czegokolwiek, co nie obejmuje „wszystkiego". Sytuacja wiersza to sytuacja, w której „wiersz szuka się poza”

35 Wydaje się, że stanowiąca motto bajka ta ma nas przekonać o tym, że tej straty nie sposób przeboleć; byłoby to etycznie nieuczciwe.

36 Zob. T. Ingold Materiały przeciwko materialności, przeł. M. Wawrzyńczak, w: Materialność, red. K. Gutfrański, A. Hendriks, I. Moreira, A. Szyłak, L. Vergara, Instytut Sztuki Wyspa, Gdańsk 2012, S. $95-125$.

K. Bartczak Wiersze organiczne, Dom Literatury w Łodzi, Łódź 2015. 
(Neofita rafinata, tamże) - poza wierszem - komunikując równocześnie o relatywności przestrzennych i jakościowych podziałów: „nie istnieje poza tym / tym wierszem co poza nim" (Koniec alienacji organizmu, tamże). Wszystkie materiały Bartczaka są jednakowo aktywnymi składnikami świata; pojawiają się w przedmiotach („sztuczny organizm wyczekuje zniknięcia”, Pieśń okienek, tamże), , przelewają się" przez nie lub wchodzą w reakcje (tworząc np. „torfemy zdaniowe" - Torfemy zdaniowe z tomu Pokarm suweren ${ }^{39}$ ). To, co metafizyczne czy duchowe (Bartczak lubi korzystać np. z kodów religijnych, odrywając je, by tak rzecz ująć, od podłoża), wynika z fizycznego: „że z plastiku jesteś i w plastik" (Polimer inic, tamże). Jak powiedziałby Ingold, w poezji Bartczaka duch jest z materii, a nie w materii (Latour mógłby to z kolei nazwać metafizyką eksperymentalną ${ }^{40}$ ). Także to, co społeczne, kulturowe, historyczne, polityczne, technologiczne, jest częścią (albo aspektem) środowiska - potrzebuje materiału, by się zdarzyć - tak jak materiał potrzebuje społecznych form, w których i z którymi będzie to środowisko tworzył. Warunkiem tych wszystkich sposobów istnienia materialności jest deesencjalizacja świata („Trans i substancja bez potrzeby wieczności [...] Trans bez istoty”, Substancja odmian trans, tamże).

Deesencjalizacja, immanencja to również punkt wyjścia w rozmowie o poezji Anny Adamowicz i Moniki Lubińskiej. Zainteresowana zwierzęcością Adamowicz eksploruje gatunkowe pogranicza, bardziej „sieciową" Lubińską interesują stany niestabilności natury, a zwłaszcza jej „nieuczesane” przedmioty (Latour).

W Animaliach ${ }^{41}$ Adamowicz zbliża do siebie gatunki, nieraz każąc im się przenikać, jak sądzę, po to, by zasugerować możliwość wspólnej dla nich koncepcji etyki. Zaczynamy więc od relacji symbiotycznych, jak w obieraniu, gdzie deklarowanemu podziałowi na wnętrze i zewnętrze ludzkiego ciała przeczy nicujący ten podział byt muszki owocówki, która dokonuje w ciele bohaterki „epistemologicznego otwarcia” - złożenie w nim jaj skutkuje poszerzeniem pola percepcji: „kontaktuję się z wszechświatem / poprzez czerwone oczy muszki owocówki". Międzygatunkowe przygody mają tu różny przebieg, inicjalne formuły w rodzaju „rośnie we mnie obce zwierzę" (pędy) czy „twoja skóra mnie pochłania” (układy, skóra) uruchamiają procesy

K. Bartczak Pokarm suweren, Biuro Literackie, Stronie Śląskie 2017.

40 Zob. B. Latour Polityka natury, s. 104.

A. Adamowicz Animalia, Biuro Literackie, Stronie Śląskie 2019. 
afektywne - oparte na materialności i otwierające na relacje z innymi. Tak pojęte afekty projektują etykę trwałości (Braidotti), dowartościowującą zoe i jej aktywną siłę. Poczucie nadmiaru, negatywności zoe może prowadzić do doświadczeń traumatycznych, dla Adamowicz istotniejsze wydaje się jednak etyczne „zrównanie w zoe". Człowiek, muszka owocówka, kret moszczący się "pod sklepieniem żeber" w trumnie czy tasiemiec Marii Callas to elementy wspólnego poliwersum. Tam jednak, gdzie etyka trwałości spotyka się z etyką ekologii walczącej, gdzie mamy do czynienia z wierszami „interpelacyjnymi" (Haraway) ${ }^{42}$, następują zaburzenia zawężające pole międzygatunkowych przepływów (w języku Mouffe i Laclau to wiązania hegemoniczne). Chodzi o sytuacje, w których podmiot-bohaterka przemawia w imieniu kolonizowanych i eksterminowanych gatunków (jak w wierszu je suis Babouin, w którym wciela się w porzuconego na stole operacyjnym - na rzecz „ludzkiego młodego" - pawiana). Ekstrapolując ludzkie w przestrzeń nie-ludzkiego, Adamowicz nie „alfabetyzuje milczących bytów" “3. Lepszym rozwiązaniem wydaje się tu „dopuszczenie do głosu” ograniczeń mowy, tak by przynajmniej czasowo zablokować mechanizm produkcji hegemonicznej ${ }^{44}$. Tak dzieje się w wierszu Adam Bochenek wstrzykuje sobie roztwór formaldehydu, którego bohater, słynny autor słynnego podręcznika do anatomii, postanawia przejść na stronę swoich preparatów, powiedzmy: „wpreparatowstąpić". Teraz, jako członek nowego kolektywu, będzie rzecznikiem bytów laboratoryjnych, przemawiającym w ich nie-ludzkim języku. Nie wiemy, jak to zrobi, ale możemy zaryzykować twierdzenie, że ta zmiana pozycji jest skuteczniejsza politycznie i radykalniejsza etycznie.

W nareszcie możemy się zjadać ${ }^{45}$ Moniki Lubińskiej - jak wskazuje tytuł również dochodzi do cielesnych spotkań, którym „patronuje” układ trawienny, ich przebieg można by za Donną Haraway nazwać wielokierunkowym przepływem ciał i wartości ${ }^{46}$. Autorka nie przekuwa metafor pokarmowych w narzędzia ekologii walczącej, schodzi poniżej poziomu utrwalonych,

42 Interpelacja - termin, który Donna Haraway przejęła od Althussera i który rozumie jako wzajemne ludzko-zwierzęce wezwanie do wspólnego bycia - trudno tu uznać za w pełni zaktualizowane, to raczej autorka "interpeluje" w imieniu zwierząt. Zob. D. Haraway Manifest gatunków stowarzyszonych, przeł. J. Bednarek, w: Teorie wywrotowe, s. 253.

Zob. tamże, s. 113.

M. Lubińska Nareszcie możemy się zjadać, Dom Literatury w Łodzi, Łódź 2019.

Zob. F. Haraway Manifest gatunków stowarzyszonych, s. 247. 
gotowych do politycznego użycia znaczeń. Interesuje ją świat w stanie naturalnej katastrofy, spowodowanej - podobnie jak było w wierszach Bartczaka - ryzykownymi układami „przedmiotów nieuczesanych" ${ }^{\text {"47 }}$ (ale właśnie raczej przedmiotów niż materiałów), których oddziaływania, z racji braku istoty i nieoczywistych relacji, w jakie wchodzą, nie sposób przewidzieć i które, jak mówi Haraway, wpływają na obfitość przepływu genów. Jak w niepokalanym poczęciu: „jestem w ciąży z fasolką szparagową / i nie wiem czy to bezpieczne dla środowiska". Lubińska lubi podkreślać, że interesujące ją byty nie mają gładkich brzegów: „chciałbym znieść wilczy margines kształtów [...] ostatni z nich był astronomicznie okrągły / w krawędziach miękki z kostnymi wypustkami”, a równocześnie te "nieuczesane przedmioty” wystawione są na działania wszelkiego rodzaju „lepiszcza”: wydzielin, śluzów, klejów. To poezja pisana z perspektywy postnaturalnej świadomości, ukształtowanej również przez teorie „końca natury”, z Latourowską na czele. Jej część stanowi oczywiście wiedza na temat zagrożeń antropocenu i szowinizmu gatunkowego, ale jest ona wykorzystywana w projektowaniu nowych połączeń, a nie w ich poetyckiej dyskursywizacji. Podmiot nie zabiera głosu w imieniu innych gatunków, ale wypróbowuje kolejne role, nieustannie zmieniając pozycje - dekonstruuje w ten sposób oczywisty układ nadrzędności/podległości. To samo dzieje się na zamieszczonych w tomie fotografiach: kobiece ciało albo bywa częścią krajobrazu, albo pokazywane jest w zbliżeniach, na których traci granice, przestaje być „ludzkie”. Tak jak w wierszach - podlega tym samym procedurom co reszta bytów, jest kłączowate, zabrudzone i skłonne do ryzykownych relacji. nareszcie możemy się zjadać to zatem również poetycki przypadek etyki trwałości.

\section{Co robić?}

Na zadane w zakończeniu Polityki natury pytanie, co robić, Bruno Latour odpowiada: „Ekologię polityczną!" ${ }^{48}$. Jest to wezwanie do zredefiniowania życia publicznego w zgodzie z ideą kompozycji wspólnego świata. Latour co prawda odżegnuje się od utopijności tej idei, nie można mieć jednak wątpliwości, że mimo iż ten wspólny świat jest faktem, wynikające z niego zobowiązania nie są i nie wiadomo, czy kiedykolwiek będą realizowane.

\footnotetext{
47 Ten termin Latoura odnosi się do przedmiotów wytwarzających kłącza i struktury sieciowe. Zob. B. Latour Polityka natury, s. 47.

48 Tamże, s. 303-311.
} 
W każdym razie wszystkie omawiane tu wiersze pracują na rzecz wspólnego świata - robią ekologię polityczną. , bronimy się jeszcze tu / w wierszach" - tak kończy swój ostatni tom, na giełdach nadprodukcji pikują akcje przetrwania ${ }^{49}$, Szczepan Kopyt.

\section{Abstract}

\section{Alina Świeściak}

UNIVERSITY OF SILESIA (KATOWICE)

What to Do? Contemporary Poetry and the Theory of Shared Worlds

Świeściak discusses the work of nine poets mostly of the young(est) generation in the context of theories related to community-based design of change- performative theories conceptualised as an intervention into social practices (Laclau and Mouffe, Deleuze and Guattari, Latour, Haraway, Barad, Stranger, Braidotti). Szczepan Kopyt, Tomasz Bąk, Adam Kaczanowski, Kamila Janiak, Konrad Góra, Kacper Bartczak, Anna Adamowicz, Monika Lubińska (and Andrzej Sosnowski as a point of departure) are presented as having an deep awareness of ecology, gender, economy, society; they are critical of the rules of postmodernity, and they imagine the utopia of a different world and rules different from the Modernist constitution. Świeściak treats their work as a weave of various discursive and material practices that hinge on the smooth reconfiguration of language and materiality.

\section{Keywords}

new materialism, shared world, antagonism, hegemonic production, utopia, anarchy, ecology of poetry, ethics of sustainability 